\title{
ERK MAP Kinase Activation in Superficial Spinal Cord Neurons Induces Prodynorphin and NK-1 Upregulation and Contributes to Persistent Inflammatory Pain Hypersensitivity
}

\author{
Ru-Rong Ji, Katia Befort, Gary J. Brenner, and Clifford J. Woolf \\ Neural Plasticity Research Group, Department of Anesthesia and Critical Care, Massachusetts General Hospital and \\ Harvard Medical School, Boston, Massachusetts 02129
}

Activation of ERK (extracellular signal-regulated kinase) MAP (mitogen-activated protein) kinase in dorsal horn neurons of the spinal cord by peripheral noxious stimulation contributes to short-term pain hypersensitivity. We investigated ERK activation by peripheral inflammation and its involvement in regulating gene expression in the spinal cord and in contributing to inflammatory pain hypersensitivity. Injection of complete Freund's adjuvant (CFA) into a hindpaw produced a persistent inflammation and a sustained ERK activation in neurons in the superficial layers (laminae I-Ilo) of the dorsal horn. CFA also induced an upregulation of prodynorphin and neurokinin-1 (NK-1) in dorsal horn neurons, which was suppressed by intra- thecal delivery of the MEK (MAP kinase kinase) inhibitor U0126. CFA-induced phospho-ERK primarily colocalized with prodynorphin and NK-1 in superficial dorsal horn neurons. Although intrathecal injection of U0126 did not affect basal pain sensitivity, it did attenuate both the establishment and maintenance of persistent inflammatory heat and mechanical hypersensitivity. Activation of the ERK pathway in a subset of nociceptive spinal neurons contributes, therefore, to persistent pain hypersensitivity, possibly via transcriptional regulation of genes, such as prodynorphin and NK-1.

Key words: ERK; MAP kinase; prodynorphin; neurokinin-1; spinal cord; inflammatory pain
Input to the spinal cord dorsal horn from high-threshold nociceptors induces central sensitization, a heterosynaptic facilitation that outlives the initiating stimulus for tens of minutes and that plays a major role in the generation of immediate postinjury pain hypersensitivity (Woolf, 1983). The increased neuronal excitability appears to result from post-translational regulation, such as phosphorylation, of key membrane receptors and channels (Woolf and Salter, 2000; Ji and Woolf, 2001).

Recently, we showed that ERK (extracellular signal-regulated kinase), a member of the MAPK (mitogen-activated protein kinase) family, is activated with a short latency ( $<1 \mathrm{~min}$ ) in superficial dorsal horn neurons by noxious but not by innocuous stimuli. This activation contributes to short-term $(<1 \mathrm{hr})$ pain hypersensitivity (Ji et al., 1999). Because the involvement of ERK activation in generating acute pain hypersensitivity can be detected well before any transcriptional change manifests, ERK activation in the spinal cord, as in the hippocampus (English and Sweatt, 1997; Impey et al., 1998, 1999; Winder et al., 1999), is likely to contribute to short-term changes in neuronal excitability by post-translational regulation.

Activated ERK is also, however, translocated to the nucleus in which it phosphorylates the transcription factor cAMP elementbinding protein (CREB), via the CREB kinase Rsk2, subsequently activating cAMP response element (CRE)-mediated

\footnotetext{
Received June 22, 2001; revised Oct. 3, 2001; accepted Oct. 26, 2001.

The work was supported by National Institutes of Health Grants RO1 NS38253 (C.J.W.) and RO1 NS40698 (R.R.J.). We thank Sara Billet for technical support, Dr. Linda Kobierski (Massachusetts General Hospital) for the prodynorphin cDNA vector, and Dr. Robert Elde (University of Minnesota) for prodynorphin antibody.

Correspondence should be addressed to Dr. Ru-Rong Ji, Neural Plasticity Research Group, Department of Anesthesia and Critical Care, Massachusetts General Hospital, Harvard Medical School, 149 13th Street, Room 4309, Charlestown, MA 02129. E-mail: ji@helix.mgh.harvard.edu.

Copyright (ㄷ) 2002 Society for Neuroscience $\quad 0270-6474 / 02 / 220478-08 \$ 15.00 / 0$
}

gene expression (Xing et al., 1996; Impey et al., 1998; Obrietan et al., 1999). ERK activation is required for long-term potentiation and long-term memory (English and Sweatt, 1997; Atkins et al., 1998; Impey et al., 1998, 1999). However, apart from immediate early genes such as $c$-fos, the specific target genes regulated by ERK responsible for long-lasting synaptic plasticity are primarily unknown (Xia et al., 1996; Sgambato et al., 1998).

Injection of irritant chemicals into a hindpaw of the rat produces a localized tissue inflammation and inflammatory pain hypersensitivity (Stein et al., 1988; Dubner and Ruda, 1992). Peripheral inflammation results in the transcriptional activation of many genes in dorsal horn neurons (Hunt et al., 1987; Wisden et al., 1990; Dubner and Ruda, 1992; Ji et al., 1994, 1995; Mannion et al., 1999; Woolf and Costigan, 1999, Samad et al., 2001), among which, prodynorphin and the substance $\mathrm{P}$ receptor neurokinin-1 (NK-1) have been intensively studied (Iadarola et al., 1988; Ruda et al., 1988; Schafer et al., 1993; McCarsson and Krause, 1994; Abbadie et al., 1996). Increased prodynorphin expression after inflammation has been suggested to be involved in the inflammation-induced enhanced excitability and subsequent development of expanded dorsal horn neuronal receptive fields (Hylden et al., 1991; Dubner and Ruda, 1992). Several lines of evidence suggest that NK-1 in the dorsal horn also plays an important role in inflammatory pain hypersensitivity (Traub, 1996; De Felipe et al., 1998; Ma et al., 1998; Woolf et al., 1998).

Noxious stimulation and inflammation induce CREB phosphorylation in dorsal horn neurons (Ji and Rupp, 1997; Messersmith et al., 1998), as well as ERK activation (Ji et al., 1999). CRE sites are present, moreover, in the promoter regions of both the prodynorphin and NK-1 genes (Hershey et al., 1991; Cole et al., 1995). This raises the possibility that the ERK pathway may play a role in regulating expression of CRE-containing genes, such as prodynorphin and $\mathrm{NK}-1$, in the dorsal horn after inflammation 
and in this way contribute to altered pain sensitivity. We now investigated this.

\section{MATERIALS AND METHODS}

Animals and drugs. Adult male Sprague Dawley rats (230-300 gm) were used according to Massachusetts General Hospital Animal Care institutional guidelines. Animals were anesthetized with pentobarbital (50 $\mathrm{mg} / \mathrm{kg}$, i.p.). Complete Freund's adjuvant (CFA) (100 $\mu \mathrm{l})$ was injected into the plantar surface of a hindpaw. For intrathecal drug delivery, a polyethylene-10 catheter was implanted into the intrathecal space of the spinal cord at the lumbar enlargement, and $10 \mu \mathrm{l}$ of the MEK (MAP kinase kinase) inhibitor U0126 (1 $\mu \mathrm{g}$; dissolved in 10\% DMSO; Calbiochem, La Jolla, CA) was administered. DMSO (10\%) was injected as vehicle control. For sustained drug delivery, an Alzet osmotic pump (3 d pump, $1 \mu \mathrm{l} / \mathrm{hr})$ was filled with the MEK inhibitor U0126 $(0.5 \mu \mathrm{g} / \mathrm{ml})$ in $50 \%$ DMSO, and the catheter of the pump was implanted intrathecally at least $3 \mathrm{hr}$ before CFA injection. DMSO (50\%) was used as vehicle control.

Immunohistochemistry. Rats were deeply anesthetized with pentobarbital $(120 \mathrm{mg} / \mathrm{kg}$, i.p.) and perfused through the ascending aorta with saline, followed by $4 \%$ paraformaldehyde with $1.5 \%$ picric acid. L4-L5 spinal cord segments were dissected and post-fixed for 2-4 hr. Transverse spinal cord sections (free floating, $30 \mu \mathrm{m}$ ) were cut and processed for immunohistochemistry using the $\mathrm{ABC}$ method as described previously (Ji et al., 1995, 1999). Briefly, sections were blocked with $2 \%$ goat serum in $0.3 \%$ Triton X-100 for $1 \mathrm{hr}$ at room temperature (RT) and incubated overnight at $4^{\circ} \mathrm{C}$ with primary antibody. The sections were then incubated for $2 \mathrm{hr}$ with biotinylated secondary antibody (1:200) and $1 \mathrm{hr}$ with ABC complex (1:50; Vector Laboratories, Burlingame, CA) at RT. Finally, the reaction product was visualized with $0.05 \%$ DAB $-0.002 \%$ hydrogen peroxide in $0.1 \mathrm{M}$ acetate buffer, $\mathrm{pH} 6.0$, containing $2 \%$ ammonium nickel sulfate for 2-5 min. Some sections were processed with immunofluorescence by incubating overnight with primary antibody and $1 \mathrm{hr}$ at RT with FITC-conjugated secondary antibody (1:300; Jackson ImmunoResearch, West Grove, PA). The following antibodies were used: anti-phospho-ERK (pERK) (also called anti-pMAPK; anti-rabbit, 1:500; New England Biolabs, Beverly, MA), anti-pERK (monoclonal; 1:300; New England Biolabs), anti-NK1 (anti-rabbit; 1:3000; Oncogene, Sciences, Uniondale, NY), and anti-prodynorphin (anti-guinea pig; 1:3000; kindly provided by Dr. R. Elde, University of Minnesota, Minneapolis, MN). Double immunofluorescence was performed by incubating a mixture of primary antibodies (mouse anti-pERK-rabbit anti-NK1 or rabbit anti-pERK-guinea pig anti-prodynorphin), followed by a mixture of corresponding secondary antibodies conjugated with either $\mathrm{Cy} 3$ or FITC.

In situ hybridization. Animals were rapidly sacrificed in a $\mathrm{CO}_{2}$ chamber, and L4-L5 spinal cord segments were removed and cut on a cryostat at a thickness of $20 \mu \mathrm{m}$. A vector (pSP65) with a $1.7 \mathrm{~kb}$ prodynorphin insert was kindly provided by Dr. Linda Kobierski (Harvard Medical School). Antisense RNA probe, and the corresponding sense control probe, were labeled by in vitro transcription using linearized DNA templates for prodynorphin and digoxigenin (DIG) labeling mixture for $2 \mathrm{hr}$ at $37^{\circ} \mathrm{C}$. Hybridization was processed as described previously (Ji et al., 1998). Tissue sections were air dried for $2 \mathrm{hr}$, fixed in $4 \%$ paraformaldehyde for $15 \mathrm{~min}$, and acetylated in acetic anhydride $(0.25 \%)$ for 10 min. Sections were prehybridized for $2 \mathrm{hr}$ at RT and then incubated in hybridization buffer overnight at $60^{\circ} \mathrm{C}$. After hybridization, sections were washed in decreasing concentrations of SSC $(2 \times, 1 \times$, and $0.2 \times)$ for $2 \mathrm{hr}$ total. Sections were then blocked with $2 \%$ goat serum for $1 \mathrm{hr}$ and incubated overnight at $4{ }^{\circ} \mathrm{C}$ with alkaline phosphatase-conjugated antiDIG antibody (1:5000; Boehringer Mannheim, Indianapolis, IN). Finally, the sections were visualized in $75 \mu \mathrm{g} / \mathrm{ml}$ nitroblue-tetrazoliumchloride, $50 \mu \mathrm{g} / \mathrm{ml}$ 5-bromo-4-chloro-3-indolyl-phosphate, and 0.24 $\mathrm{mg} / \mathrm{ml}$ levamisole for $2-24 \mathrm{hr}$.

RNase protection. Dynorphin cDNA was generated by reverse transcription-PCR from rat DRG total RNA, using primers 5'-TGGAAAAGCCCAGCTCCTAGACCCT-3' and 5'-TTCCTCGTGGGCTTGAAGTGTGAAA-3' and cloned into pCRII (Invitrogen, San Diego, CA). The plasmid was linearized with $E c o \mathrm{RV}$, and an antisense probe was synthesized using Sp6 RNA polymerase and labeled with [ $\left.{ }^{32} \mathrm{P}\right] \mathrm{UTP}(800 \mathrm{Ci} /$ mmol; NEN, Boston, MA). RNase protection assays (RPAs) were performed using the RPA III (Ambion, Austin, TX) protocol, as reported previously (Samad et al., 2001). Briefly, $10 \mu \mathrm{g}$ of RNA samples were hybridized with labeled probe overnight at $42^{\circ} \mathrm{C}$ and then digested with RNase A/RNase $\mathrm{T} 1 \mathrm{mix}$ in RNase digestion buffer for $30 \mathrm{~min}$ at $37^{\circ} \mathrm{C}$.
Finally, samples were separated on denaturing acrylamide gel and exposed to x-ray films. A $\beta$-actin probe was used for each sample as loading controls.

Western blot. Animals were sacrified, and dorsal horns of the L4-L5 spinal segments were rapidly removed and homogenized with a handheld pellet pestle in lysis buffer containing a cocktail of phosphatase inhibitors $(100 \times)$ and proteinase inhibitors $(25 \times$; Sigma, St. Louis, MO). For NK-1 protein, the dorsal horns were directly homogenized in boiling SDS sample buffer (100 mm Tris, pH6.8, 2\% SDS, $20 \%$ glycerol, $10 \%$ $\beta$-mercaptoethanol, and $0.1 \%$ bromophenol blue). Protein samples were separated on SDS-PAGE gel (4-15\% gradient gel; Bio-Rad, Hercules, $\mathrm{CA}$ ) and transferred to polyvinylidene difluoride filters (Millipore, Bedford, MA). The filters were blocked with $3 \%$ milk and incubated overnight at $4^{\circ} \mathrm{C}$ with polyclonal anti-pERK (1:1000; New England Biolabs) or anti-NK-1 (1:5000; Oncogene Sciences) primary antibody. The blots were incubated for $1 \mathrm{hr}$ at RT with HRP-conjugated secondary antibody (1:3000; Amersham Biosciences, Arlington Heights, IL) and visualized in ECL solution (NEN, Boston, MA) for $1 \mathrm{~min}$ and exposed onto hyperfilms (Amersham Biosciences) for 1-30 min. The blots were then incubated in stripping buffer $(67.5 \mathrm{~mm}$ Tris, $\mathrm{pH} 6.8,2 \%$ SDS, and $0.7 \%$ $\beta$-mercaptoethanol) for $30 \mathrm{~min}$ at $50^{\circ} \mathrm{C}$ and reprobed with polyclonal anti-ERK or anti-CREB antibody (1:3000; New England Biolabs) as loading controls.

Behavioral analysis. Animals were habituated to the testing environment daily for $2 \mathrm{~d}$ before baseline testing. Except for the heat test, all of the animals were placed on an elevated wire grid. For mechanical allodynia, the plantar surface of the hindpaw was stimulated with a series of von Frey hairs. The threshold was taken as the lowest force that evokes a brisk withdrawal response. For heat hyperalgesia, the plantar surface of a hindpaw was exposed to a beam of radiant heat through a transparent Perspex surface (Hargrevas et al., 1988). The withdrawal latency was recorded, with a maximum $15 \mathrm{sec}$ as cutoff. The withdrawal latency was averaged over three trials.

Quantification and statistics. Eight nonadjacent sections from the L4-L5 lumbar spinal cord were randomly selected, and the numbers of immunoreactive or mRNA-positive neuronal profiles in the superficial laminae and/or deep laminae of the dorsal horn in each section were counted (under a $20 \times$ object field) by an observer blind to the treatment. The values from the eight sections were averaged for each animal. The data are represented as mean \pm SEM. For RNase protection and Western blots, each experiment was repeated at least twice, and, in all cases, the same results were obtained. The density of specific bands was measured with a computer-assisted imaging analysis system (IP Lab software) and normalized against a loading control. Differences between groups were compared using Student's $t$ test or ANOVA, followed by Fisher's PLSD. For nonparametric data, Mann-Whitney $U$ test was applied. The criterion for statistical significance was $p<0.05$.

\section{RESULTS}

\section{ERK activation by peripheral inflammation}

To investigate whether ERK is activated by peripheral inflammation, we injected $100 \mu \mathrm{l}$ of CFA into the plantar surface of a hindpaw under pentobarbital anesthesia $(50 \mathrm{mg} / \mathrm{kg}$, i.p). This produced an area of localized swelling, erythema, and hypersensitivity to mechanical and thermal stimuli, which persisted for the duration of the experiment ( $48 \mathrm{hr}$ ). The inflammation induced by the CFA injection resulted in the induction of $\mathrm{pERK}$ in neurons in the medial superficial dorsal horn on the ipsilateral side of the lumbar enlargement (Fig. 1a,b). No induction was found in the contralateral spinal cord (Fig. 1a). Intraplantar injection of saline (100 $\mu \mathrm{l}$ ) only induced a very weak pERK induction (data not shown). The CFA-induced pERK was found only in neurons; all pERK cells expressed neuronal-specific nuclear protein, a marker for neuronal cells (data not shown). The pERK-labeled neurons were predominantly localized in laminae I-IIo, and the pERK was present in the nucleus, cytoplasm, and dendrites, as reported previously (Ji et al., 1999). The number of pERK neurons peaked at $10 \mathrm{~min}$ but remained elevated with a slow decline for $48 \mathrm{hr}$ (Fig. 1c). This temporal pattern differs substantially from the transient $(<2 \mathrm{hr})$ ERK activation evoked by intraplantar capsaicin (Ji et al., 


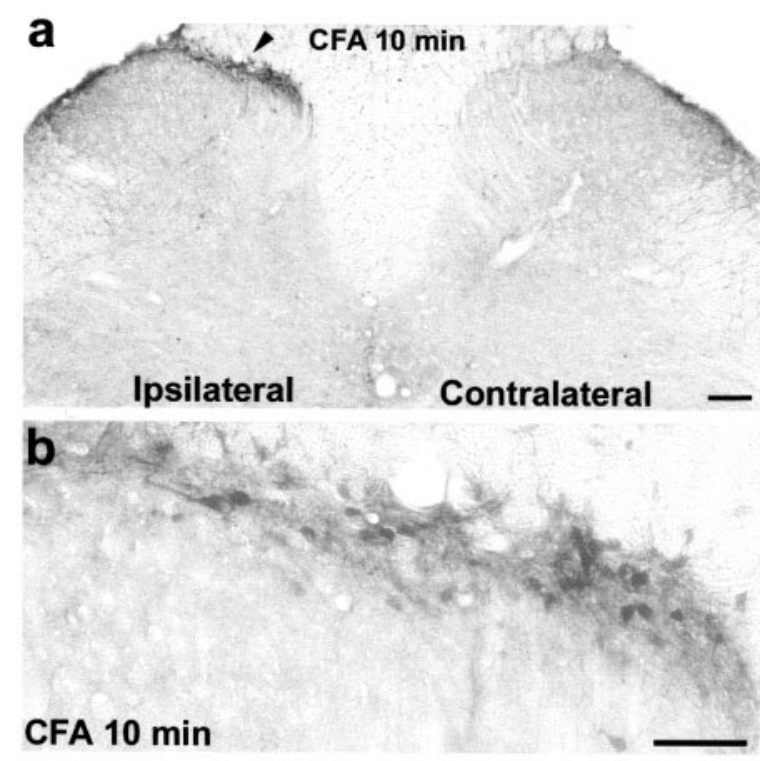

C

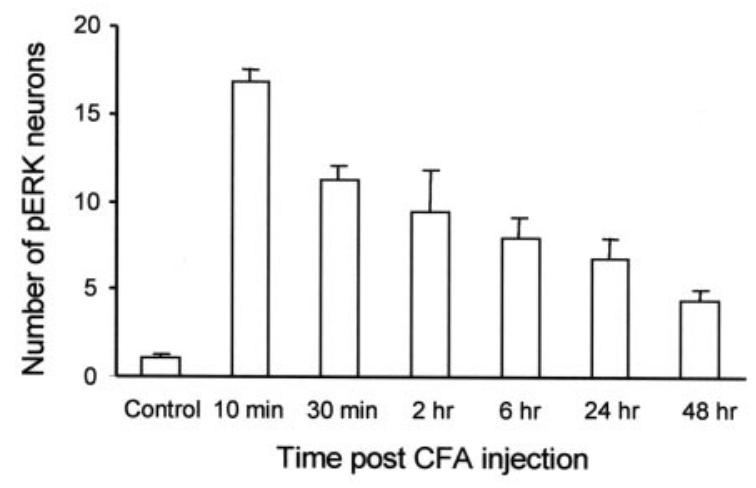

d

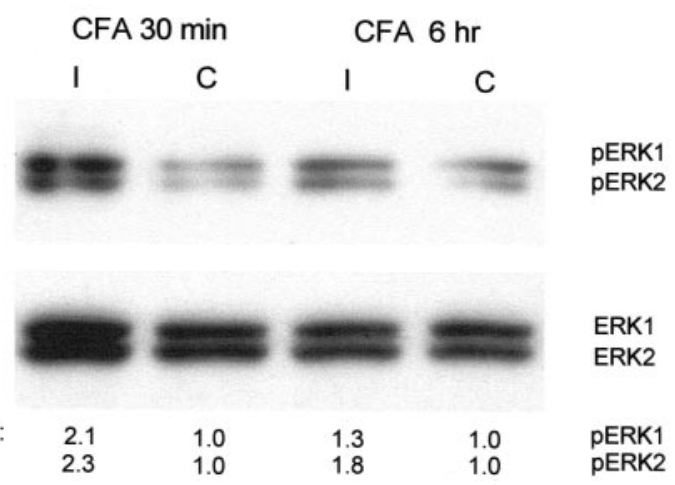

Figure 1. CFA induces a sustained activation of ERK. $a$, A lowmagnification image showing induction of ERK phosphorylation in laminae I-IIo neurons of the ipsilateral spinal cord (indicated with an arrowhead) $10 \mathrm{~min}$ after CFA injection into a hindpaw. Scale bar, $200 \mu \mathrm{m}$. $b$, A high-magnification image of $a$, showing ERK activation in the medial superficial dorsal horn of the ipsilateral spinal cord $10 \mathrm{~min}$ after CFA injection. Scale bar, $50 \mu \mathrm{m}$. $c$, Time course of pERK induction after CFA administration measured by the number of pERK-positive neurons in the superficial (I-IIo) layers of the ipsilateral dorsal horn. Data are represented as mean $\pm \operatorname{SEM}(n=3)$. $d$, Western blot showing increased ERK phosphorylation of both ERK1 (44 kDa) and ERK2 (42 kDa) in the ipsilateral $(I)$ dorsal horn compared with contralateral $(C)$ side, $30 \mathrm{~min}$ and $6 \mathrm{hr}$ after CFA injection. The bottom panel indicates levels of total ERK1 and ERK2, as loading controls. Fold represents comparative levels over the corresponding contralateral side after normalizing for loading.
1999). ERK activation by CFA was confirmed by Western blot analysis. The phosphorylation level of both ERK1 (44 kDa) and ERK2 (42 kDa) increased in the ipsilateral dorsal horn compared with the contralateral side at $30 \mathrm{~min}$ and $6 \mathrm{hr}$ (Fig. 1d). Because ERK is only activated in a small subset of dorsal horn neurons, Western blot is less sensitive than immunohistochemistry in detecting ERK activation in the superficial dorsal horn.

Because pERK reached a peak level very rapidly (10 min) after the CFA injection, we tested whether the CFA also produced hyperalgesia at this time. CFA $(100 \mu \mathrm{l})$ injected into the plantar surface of hindpaw in awake rats produced both immediate erythema and a rapid heat hyperalgesia. The paw-withdrawal latency (in seconds) decreased by $60 \%$ (from $10.8 \pm 0.4$ to $4.3 \pm$ $0.7 ; p<0.01 ; t$ test; $n=3$ ) and $50 \%$ (from $9.7 \pm 1.2$ to $4.9 \pm 1.3$; $p<0.05)$ at 10 and $30 \mathrm{~min}$, respectively. Saline-injected rats did not show any heat hypersensitivity.

\section{Prodynorphin induction by inflammation}

To investigate changes in the expression of prodynorphin in response to inflammation, we used RPA, in situ hybridization, and immunohistochemistry. The peripheral inflammation resulted in a substantial upregulation of prodynorphin mRNA in the ipsilateral spinal dorsal horn 24 and $48 \mathrm{hr}$ after CFA injection, as detected by the RPA (Fig. $2 a$ ). With the in situ hybridization, many strongly labeled prodynorphin mRNA-labeled neurons were found both in the superficial and deep layers of the ipsilateral dorsal horn $24 \mathrm{hr}$ after CFA injection, whereas on the contralateral side, only a few weakly labeled neurons were detected (Fig. 2b). An increase in the number of prodynorphin peptide immunoreactive neurons was also found in the superficial and deep dorsal horn $48 \mathrm{hr}$ after the CFA-induced inflammation (Fig. 2c).

\section{ERK activation and prodynorphin expression}

We then investigated whether prodynorphin mRNA expression in the dorsal horn is regulated by ERK activation. A specific and potent MEK inhibitor, U0126 (Favata et al., 1998), was intrathecally injected twice $(1 \mu \mathrm{g}), 30 \mathrm{~min}$ before and $6 \mathrm{hr}$ after intraplantar CFA injection. This reduced the CFA-induced prodynorphin mRNA increase in the ipsilateral dorsal horn, as detected by the RPA (Fig. 3a). The CFA-evoked increase in the number of prodynorphin mRNA-positive neurons in the superficial dorsal horn was also decreased by U0126 $(2 \times 1 \mu \mathrm{g})$ without any effect on the number of labeled neurons in the deep laminae, as detected by in situ hybridization (Fig. 3b,c).

\section{ERK activation and NK-1 expression}

In agreement with previous studies (Abbadie et al., 1996, 1997), we observed increased NK-1 immunoreactivity in the superficial dorsal horn after CFA-induced inflammation using both immunohistochemistry and Western blot analysis (Fig. 4a,c). However, in contrast to the previous studies (Abbadie et al., 1997; Honore et al., 1999), we found more NK-1-expressing cells after inflammation compared with our control (Fig. 4a,b). This discrepancy is attributable to the different detection thresholds for NK-1positive neurons; our quantification, based on standard DAB staining, did not include weakly stained cells in control animals. These cells would be detected with confocal microscopy (Abbadie et al., 1997; Honore et al., 1999). The increase in NK-1immunoreactive neurons we detected in lamina I (Fig. $4 a$ ) reflects the increase in staining intensity seen by others (Abbadie et al., 1997; Honore et al., 1999) in this lamina. To explore whether ERK activation is involved in the NK-1 upregulation, the MEK 
ล

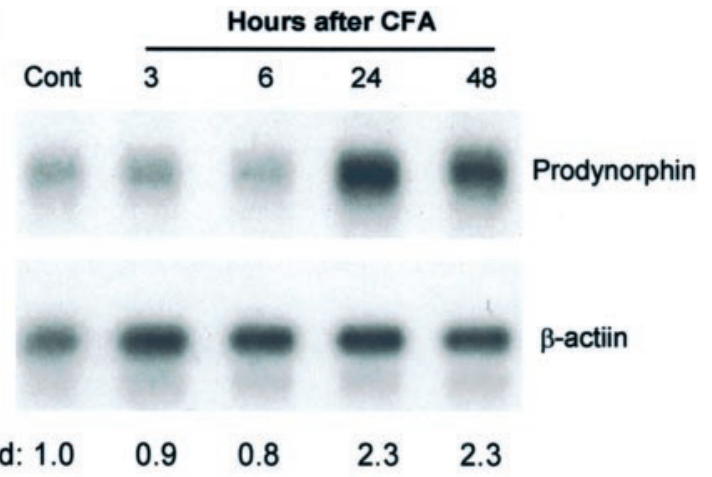

b

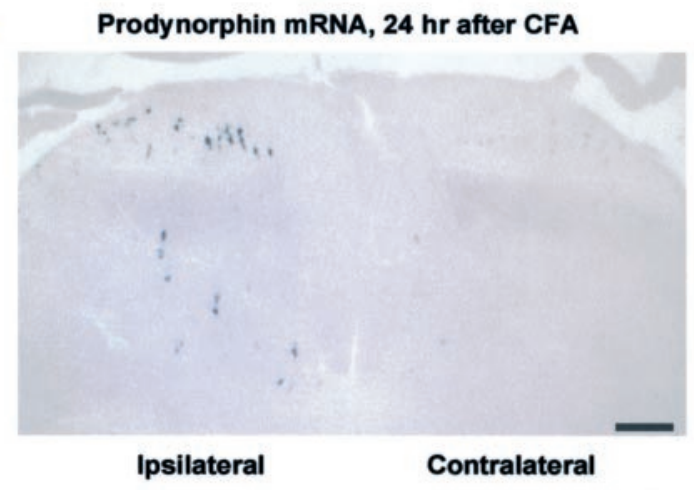

C

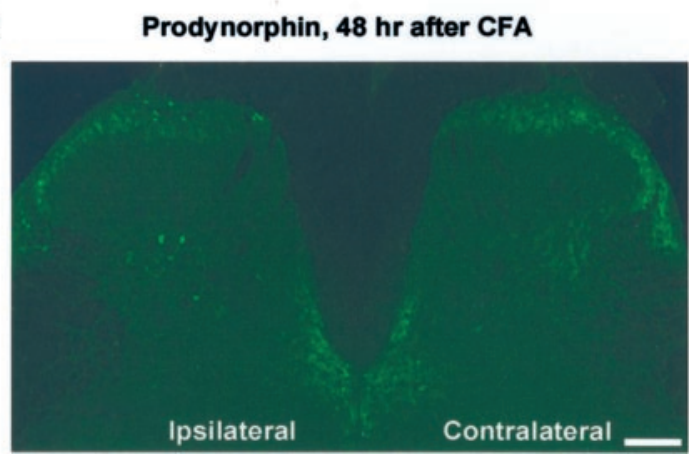

Figure 2. CFA induces prodynorphin upregulation in the dorsal horn. $a$, An RNase protection assay reveals an increase in prodynorphin mRNA in the ipsilateral dorsal horn 24 and $48 \mathrm{hr}$ after CFA injection. Fold represents comparative levels over control after normalizing for loading. $b$, In situ hybridization indicates an increased expression of prodynorphin mRNA in ipsilateral superficial and deep dorsal horn neurons $24 \mathrm{hr}$ after CFA. Scale bar, $50 \mu \mathrm{m}$. $c$, Increased number of prodynorphinimmunoreactive neurons was induced in the ipsilateral superficial and deep dorsal horn by CFA injection at $48 \mathrm{hr}$. Scale bar, $50 \mu \mathrm{m}$.

inhibitor U0126 was delivered intrathecally before the induction of inflammation via an osmotic pump $\left(0.5 \mu \mathrm{g} \cdot \mu \mathrm{l}^{-1} \cdot \mathrm{hr}^{-1}\right.$ for 2 d). MEK inhibition suppressed the CFA-induced elevation of NK-1-immunoreactive neurons in the superficial dorsal horn (Fig. 4a,b). A Western blot analysis confirmed this (Fig. 4c). The NK-1 antibody recognized a single band of $\sim 46 \mathrm{kDa}$, which corresponds to the predicted molecular weight of cloned NK-1 receptor (Hershey and Krause, 1990).

To test whether the pERK-positive neurons and prodynorphin-NK-1-expressing neurons belong to same subset of dorsal horn cells, we performed double immunofluorescence for pERKprodynorphin and for pERK-NK-1. Almost all prodynorphin- a

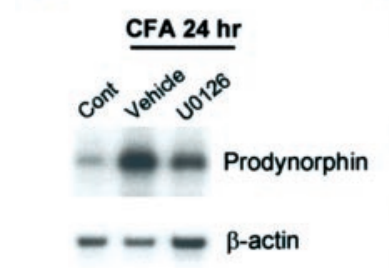

Fold: $1.0 \quad 3.71 .8$

C

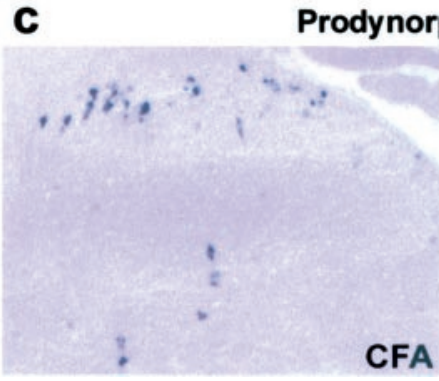

CFA

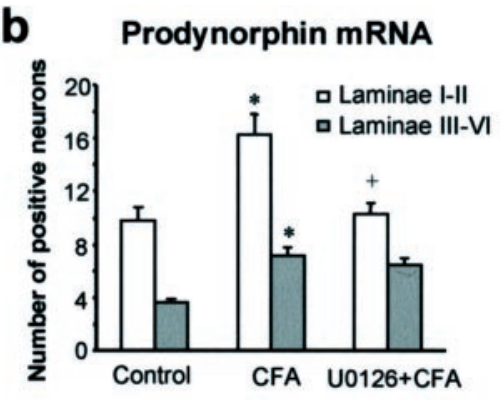

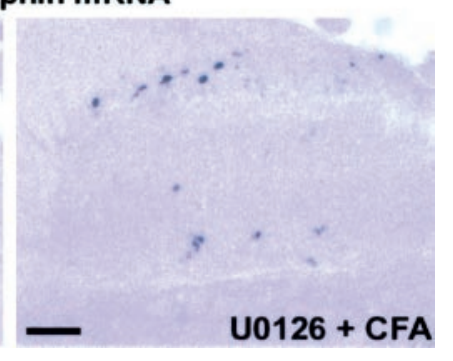

Figure 3. ERK activation regulates prodynorphin expression. $a$, Partial suppression of the CFA-induced increase in prodynorphin mRNA in the dorsal horn at $24 \mathrm{hr}$ by U0126 (1 $\mu \mathrm{g}$, intrathecally injected $30 \mathrm{~min}$ before and $6 \mathrm{hr}$ after CFA). Fold represents comparative levels over control after normalizing for loading. $b$, Quantification of prodynorphin mRNApositive neurons in laminae I-II and III-VI of the ipsilateral dorsal horn $24 \mathrm{hr}$ after CFA injection. * $p<0.001$, compared with control; $+p<0.001$, compared with CFA $(n=4)$. $c$, In situ hybridization showing an inhibition of the CFA-induced increase in prodynorphin mRNA-labeled neurons in the superficial dorsal horn by U0126 $24 \mathrm{hr}$ after CFA injection. Scale bar, $50 \mu \mathrm{m}$.

and NK-1-positive neurons in the superficial dorsal horn also express pERK $24 \mathrm{hr}$ after CFA injection (Fig. 5).

\section{ERK activation and persistent inflammatory pain}

To examine the functional consequences of ERK activation and its downstream effects on prodynorphin and NK-1 upregulation, we tested whether inhibition of ERK activation modified inflammatory pain hypersensitivity. Intrathecal administration of U0126 (1 $\mu \mathrm{g})$ into non-inflamed animals, like another MEK inhibitor PD 98059 (Ji et al., 1999), produced no significant change in basal pain sensitivity measured in terms of mechanical withdrawal threshold ( $108 \%$ of the vehicle control) and heat withdrawal latency ( $113 \%$ of vehicle control), when tested $30 \mathrm{~min}$ after the administration. However, intrathecal administration of U0126 via an osmotic pump $\left(0.5 \mu \mathrm{g} \cdot \mu \mathrm{l}^{-1} \cdot \mathrm{hr}^{-1}\right)$, started before the CFA injection and maintained for $48 \mathrm{hr}$, significantly reduced the inflammation-induced heat and mechanical hypersensitivity measured at 24 and $48 \mathrm{hr}$ (Fig. $6 a, b)$.

Acute pain hypersensitivity (10-60 min after an intraplantar formalin injection) is reduced by inhibition of ERK activation, presumably by preventing post-translational changes (Ji et al., 1999). ERK activation by CFA could conceivably contribute to inflammatory pain hypersensitivity by either maintaining ongoing post-translational changes or inducing transcription of genes, such as prodynorphin and NK-1. In the former case, blocking ERK activation in established inflammation would be expected to reduce the pain hypersensitivity within tens of minutes as the substrates were dephosphorylated. If the contribution of ERK activation were through transcription, however, inhibiting ERK activation would be expected to have no immediate effect but 
a
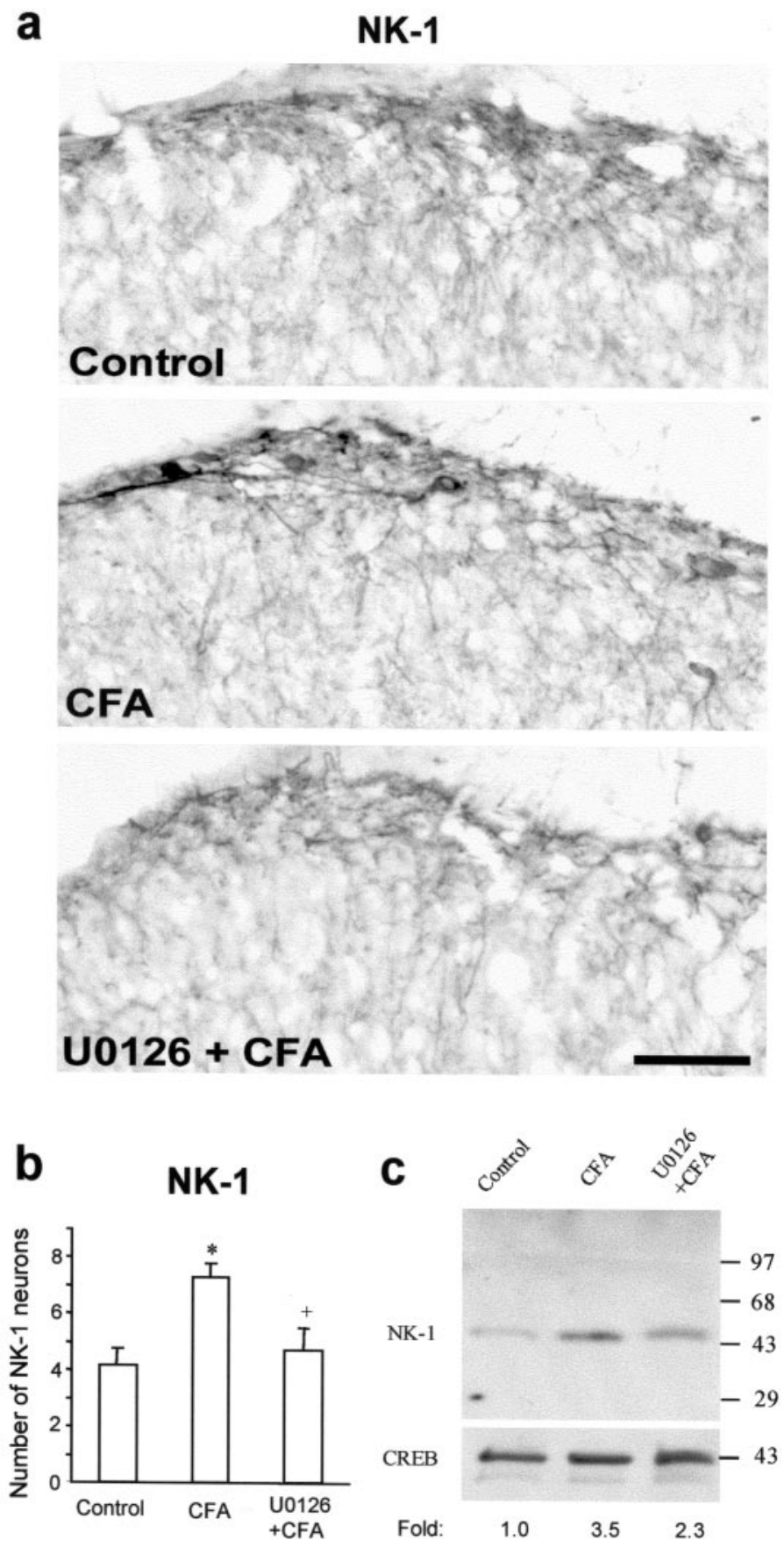

Figure 4. ERK activation regulates NK-1 expression. $a$, Suppression of the CFA-induced increase in NK-1 immunoreactivity in the medial superficial dorsal horn at $48 \mathrm{hr}$ by U0126 delivered via an osmotic pump. Scale bar, $50 \mu \mathrm{m}$. $b$, Quantification of the numbers of NK-1 neurons in laminae I-IIo of the ipsilateral dorsal horn $48 \mathrm{hr}$ after CFA injection. * $p<$ 0.001 , compared with control; $+p<0.001$, compared with CFA $(n=5)$. $c$, Western blot indicates that the CFA-induced NK-1 increase in the dorsal horn at $24 \mathrm{hr}$ is inhibited by U0126 $(1 \mu \mathrm{g}$, intrathecally injected 30 min before and $6 \mathrm{hr}$ after CFA injection). CREB, a constitutively expressed protein, was used as a loading control. Fold represents comparative levels over control after normalizing for loading.

rather a delayed effect. To test this, we intrathecally injected U0126 $(1 \mu \mathrm{g})$ in rats with established inflammation (24 hr after CFA injection) and tested pain hypersensitivity $30 \mathrm{~min}, 6 \mathrm{hr}$, and $24 \mathrm{hr}$ after the U0126 injection. Neither heat hyperalgesia nor mechanical allodynia was significantly affected by such posttreatment when tested at $30 \mathrm{~min}$ (Fig. 7a,b). However, the posttreatment decreased heat hyperalgesia at $24 \mathrm{hr}$ and mechanical allodynia at $6 \mathrm{hr}$ (Fig. 7a,b), indicating a long-latency contribution of ERK activation to the maintenance of persistent inflammatory pain.

\section{DISCUSSION}

\section{ERK activation in nociceptive dorsal horn neurons}

Peripheral inflammation induced, after a short latency, a persistent activation of ERK in laminae I-IIo neurons of the ipsilateral superficial dorsal horn. Inhibition of this activation, using an MEK inhibitor, blocked elevation of prodynorphin and NK-1 expression in this particular subset of dorsal horn neurons, as well as reduced inflammatory pain hypersensitivity. pERK was induced by CFA in the same subset of dorsal horn neurons that express prodynorphin and NK-1. Many NK-1- and dynorphinexpressing neurons in lamina I are projection neurons (Nahin et al., 1989; Marshall et al., 1996). Projection neurons in lamina I exhibit an enlargement of their receptive fields after CFAinduced inflammation (Dubner and Ruda, 1992). A targeted loss of NK-1-expressing neurons in lamina $I$ has been shown to abolish inflammatory pain (Nichols et al., 1999). These studies indicate a critical role for the aforementioned superficial neurons in the reaction of the CNS to inflammation. A particular subset of C-nociceptor fibers, those that are NGF-responsive, and TrkAand neuropeptide-expressing, terminate in laminae I and IIo, in an area overlapping the neurons that show ERK activation. Another subset of C-fibers, those that respond to the glial cell line-derived neurotrophic factor family of growth factors and are characterized by selective binding of the IB4 lectin, terminate in lamina IIi (Averill et al., 1995; Molliver et al., 1997). The neurons these fibers contact, many of which contain PKC $\gamma$ (Malmberg et al., 1997), do not show ERK activation after capsaicin or CFA injection (R.-R. Ji et al., unpublished observations). The role of ERK in regulating pain hypersensitivity is, therefore, restricted to a particular subset of nociceptive dorsal horn neurons, only those located in laminae I-IIo, and this activation is likely to reflect activation only of TrkA-expressing C-fibers.

\section{Transcriptional regulation in response to ERK activation}

pERK was found in the nucleus of neurons after CFA injection (Fig. 1a), pointing to a possible transcriptional role for the activated kinase. Unlike the transient activation (lasting $<2 \mathrm{hr}$ ) induced after capsaicin injection (Ji et al., 1999), CFA produced persistent ERK activation (Fig. 1c). The sustained ERK activation after CFA injection is associated with persistent upregulation of prodynorphin mRNA (lasting $>48 \mathrm{hr}$ ) (Fig. $2 a$ ), whereas the transient pERK induced by capsaicin is associated with a shorterlasting upregulation of prodynorphin mRNA $(<6 \mathrm{hr}$; R.-R. Ji and C. J. Woolf, unpublished observation). ERK activation is likely to regulate the expression of prodynorphin and $\mathrm{NK}-1$, both of which are CRE-containing genes, via CREB phosphorylation. CREB is required for dopamine-induced expression of prodynorphin in striatal neurons (Cole et al., 1995) and is phosphorylated in NK-1 receptor-expressing neurons after noxious stimulation (Anderson and Seybold, 2000). Interestingly, a CRE site has been shown to mediate a long-term sensitization of nociceptive neurons in Aplysia (Lewin and Walters, 1999). 

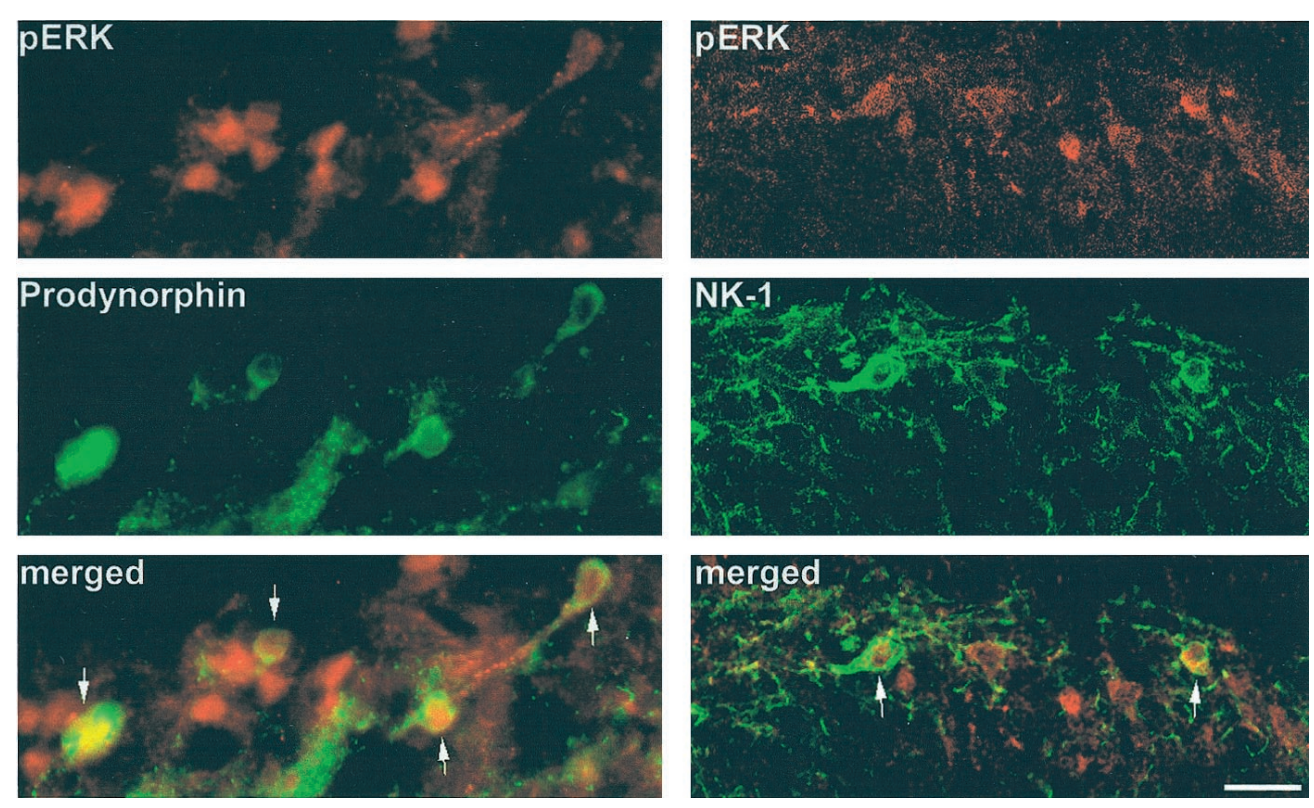

Figure 5. ERK is activated in a subset of prodynorphin- and NK-1-expressing neurons. pERK (red) is primarily colocalized with prodynorphin (green; left) and NK-1 (green; right) in the medial superficial dorsal horn $24 \mathrm{hr}$ after CFA injection. Arrows indicate double-labeled neurons. Scale bar, $20 \mu \mathrm{m}$.
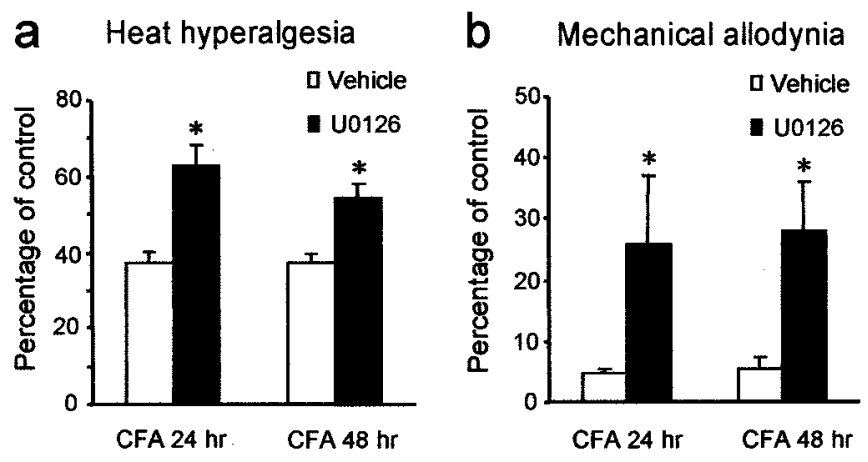

Figure 6. Sustained infusion of an MEK inhibitor reduces CFA-induced inflammatory pain. The MEK inhibitor U0126 delivered by osmotic pump $\left(0.5 \mu \mathrm{g} \cdot \mu \mathrm{l}^{-1} \cdot \mathrm{hr}^{-1}\right)$ before CFA injection reduces thermal hyperalgesia ( $a$ ) and mechanical allodynia (b) 24 and $48 \mathrm{hr}$ after CFA injection. These were measured by paw-withdrawal latency and paw-withdrawal threshold, respectively, and expressed as percentage of pre-CFA baseline measurements of vehicle control (50\% DMSO). ${ }^{*} p<0.01$, compared with corresponding vehicle control $(n=8)$.

\section{ERK activation and inflammatory pain hypersensitivity}

U0126 is a potent and selective MEK inhibitor (Favata et al., 1998), achieving inhibition of ERK activation even in the face of strong activators, such as phorbol esters, whereas other major signal transduction pathways are not affected (Roberson et al., 1999). This inhibitor has not only been used in in vitro studies (Roberson et al., 1999) but also in in vivo studies (Han and Holtzman, 2000; Kuroki et al., 2001). At the dose we used, we did not find obvious toxicity of this inhibitor, animals behaved normally, and locomotion was unaffected. Although basal pain sensitivity was not affected by the inhibitor, persistent inflammatory pain was reduced. This could conceivably result from either preventing some post-translational change mediated by the ERK signal transduction pathway, as for acute pain hypersensitivity (Ji et al., 1999), or a reduction in transcription of target genes, such as prodynorphin and NK-1. The involvement suggested by a number of different studies, of both the NK-1 receptor and prodynorphin in pain mechanisms, together with their regulation by ERK activation, is compatible with a hypothesis that ERK activation after inflammation contributes to pain hypersensitivity by regulating gene transcription. The temporal profile of the effect of blocking ERK activation represents additional support. The acute pain hypersensitivity established within minutes of intraplantar formalin can be reduced by preventing ERK activation (Ji et al., 1999), an effect that is too quick ( $<1 \mathrm{hr})$ to be mediated by an inhibition of transcription and is likely therefore to represent some post-translational change downstream of the activated ERK. At present, it is not clear what the substrate for such post-translational change is, but it may well be an ion channel or receptor, such as the NMDA or AMPA receptor (Woolf and Salter, 2000). Such post-translational changes underlie the induction and maintenance of central sensitization, a use-dependent plasticity that outlasts its initiating stimulus by tens of minutes (Woolf, 1983; Woolf and Wall, 1986). If inflammatory hypersensitivity were a manifestation only of a central sensitization maintained by ongoing afferent input from the inflamed tissue, then blocking the initiation of central sensitization, by inhibiting an ERK-mediated phosphorylation, should reduce the hypersensitivity over a periods of tens of minutes as the key proteins were dephosphorylated. The fact that MEK inhibition during established inflammation had no immediate effect, but rather only reduced mechanical and thermal hypersensitivity 6-24 hr later, argues that the role of ERK activation may well be via transcriptional regulation.

\section{Dynorphin and NK-1 contribute to inflammatory pain hypersensitivity}

A temporal correlation has been shown previously between the expression of prodynorphin and NK-1 and development of inflammatory pain hypersensitivity (Iadarola et al., 1988; Abbadie et al., 1996). Unlike other opioid peptides, intrathecal injection of dynorphin does not produce analgesia (Laughlin et al., 1997). Dynorphin has actually been found to be pronociceptive in some pathological pain states. For example, dynorphin A antiserum reduces the pain hypersensitivity after nerve injury (Nichols et al., 1997; Wegert et al., 1997; Malan et al., 2000), and neuropathic pain does not persist in prodynorphin knock-out mice (Wang et al., 2001). The pronociceptive action of dynorphin appears to be the result of its nonopioid actions (Laughlin et al., 1997), includ- 
a

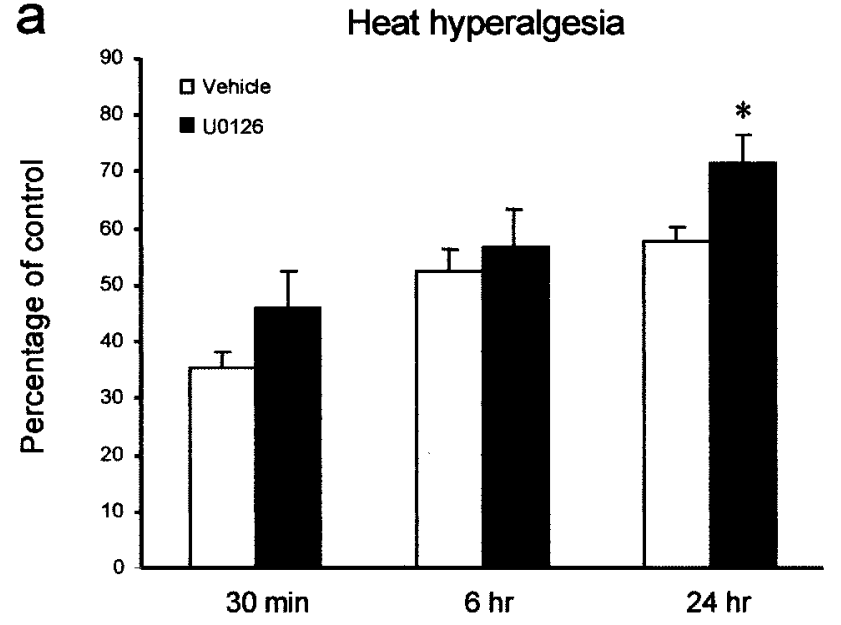

b

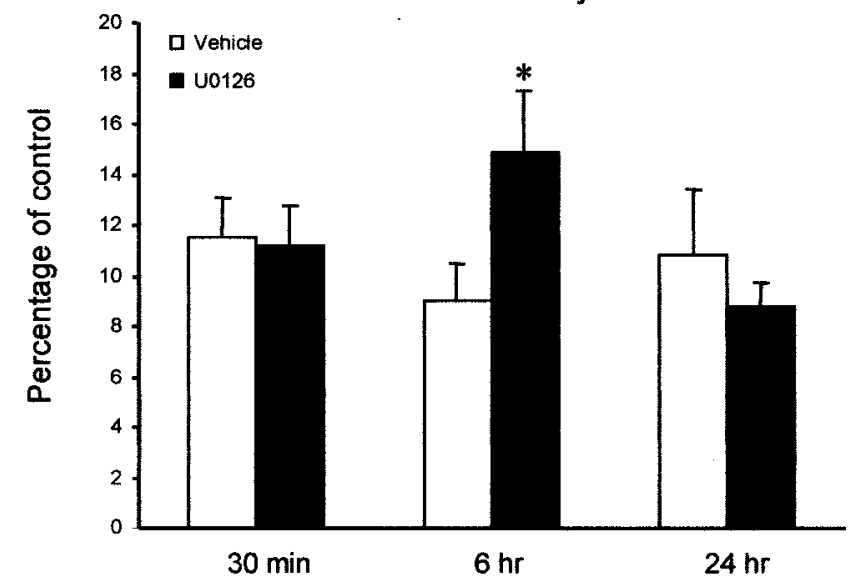

Figure 7. Post-treatment with an MEK inhibitor has a delayed effect on inflammatory pain. U0126 $(1 \mu \mathrm{g})$ or vehicle $(10 \%$ DMSO) was intrathecally administered $24 \mathrm{hr}$ after CFA injection. Heat hyperalgesia $(a)$ and mechanical allodynia $(b)$ were tested $30 \mathrm{~min}, 6 \mathrm{hr}$, and $24 \mathrm{hr}$ after the administration of the U0126. ${ }^{*} p<0.05$, compared with corresponding vehicle control $(n=10)$. The data are expressed as percentage of preCFA baseline measurements of vehicle control.

ing an activation of NMDA receptors sufficient to induce excitotoxicity (Dubner and Ruda, 1992).

Inflammation induces NK-1 receptor upregulation in dorsal horn neurons and upregulation of its ligand, the neuropeptide substance P, in primary afferent neurons (Noguchi et al., 1988; Abbadie et al., 1996) (also see Woolf et al., 1998). NK-1 antagonists have been shown to reduce inflammatory pain (both hyperalgesia and mechanical allodynia) in several different animal models (Neumann et al., 1996; Ren et al., 1996; Traub, 1996; Ma et al., 1998; Woolf et al., 1998; Trafton and Basbaum, 2000), including NK-1 knock-out mice (De Felipe et al., 1998). The increased amount and internalization of the NK-1 receptor on the dendrites of dorsal horn neurons in response to noxious and innocuous stimuli after inflammation indicates that this receptor is activated by substance $\mathrm{P}$ in response to peripheral stimuli (Abbadie et al., 1997).

\section{Conclusion}

ERK activation has two roles in nociceptive plasticity in the dorsal horn: a short-latency contribution to acute noxious stimulus-induced central sensitization and an involvement in the induction and maintenance of inflammatory pain. The involvement of pERK in peripheral inflammatory pain hypersensitivity may be contributed to by its regulation of prodynorphin and NK-1 expression, as well as other target genes. ERK activation plays, therefore, a pivotal role in the functional plasticity and chemical phenotype of a group of neurons in the superficial dorsal horn, determining the activation of particular effector responses to divergent inputs, which in turn contribute to altered sensibility.

\section{REFERENCES}

Abbadie C, Brown JL, Mantyh PW, Basbaum AI (1996) Spinal cord substance $\mathrm{P}$ receptor immunoreactivity increases in both inflammatory and nerve injury models of persistent pain. Neuroscience 70:201-209.

Abbadie C, Trafton J, Liu H, Mantyh PW, Basbaum AI (1997) Inflammation increases the distribution of dorsal horn neurons that internalize the neurokinin-1 receptor in response to noxious and non-noxious stimulation. J Neurosci 17:8049-8060.

Anderson LE, Seybold VS (2000) Phosphorylated cAMP response element binding protein increases in neurokinin-1 receptorimmunoreactive neurons in rat spinal cord in response to formalininduced nociception. Neurosci Lett 283:29-32.

Atkins CM, Selcher JC, Petraitis JJ, Trzaskos JM, Sweatt JD (1998) The MAPK cascade is required for mammalian associative learning. Nat Neurosci 1:602-609.

Averill S, McMahon SB, Clary DO, Reichardt LF, Priestley JV (1995) Localization of trkA receptors in chemically identified subgroups of adult rat sensory neurones. Eur J Neurosci 7:1484-1494.

Cole RL, Konradi C, Douglass J, Hyman SE (1995) Neuronal adaptation to amphetamine and dopamine: molecular mechanisms of prodynorphin gene regulation in rat striatum. Neuron 14:813-823.

De Felipe C, Herrero JF, O'Brien JA, Palmer JA, Doyle CA, Smith AJ, Laird JM, Belmonte C, Cervero F, Hunt SP (1998) Altered nociception, analgesia and aggression in mice lacking the receptor for substance P. Nature 392:394-397.

Dubner R, Ruda MA (1992) Activity-dependent neuronal plasticity following tissue injury and inflammation. Trends Neurosci 15:96-103.

English JD, Sweatt JD (1997) A requirement for the mitogen-activated protein kinase cascade in hippocampal long term potentiation. J Biol Chem 272:19103-19106.

Favata M, Horiuchi KY, Manos EJ, Daulerio AJ, Stradley DA, Feeser WS, Van Dyk DE, Pitts WJ, Earl RA, Hobbs F, Copeland RA, Magolda RL, Scherle PA, Trzaskos JM (1998) Identification of a novel inhibitor of mitogen-activated protein kinase kinase. J Biol Chem 273:18623-18632.

Han BH, Holtzman DM (2000) BDNF protects the neonatal brain from hypoxic-ischemic injury in vivo via the ERK pathway. J Neurosci 20:5775-5781.

Hargrevas K, Dubner R, Brown F, Flores C, Joris J (1988) A new and sensitive method for measuring thermal nociception in cutaneous hyperalgesia. Pain 32:77-88.

Hershey AD, Krause JE (1990) Molecular characterization of a functional cDNA encoding the rat substance $\mathrm{P}$ receptor. Science 247:958-962.

Hershey AD, Dykema PE, Krause JE (1991) Organization, structure and expression of the gene encoding the rat substance P receptor. J Biol Chem 266:4366-4374

Honore P, Menning PM, Rogers SD, Nichols ML, Basbaum AI, Besson JM, Mantyh PW (1999) Spinal substance P receptor expression and internalization in acute, short-term, and long-term inflammatory pain states. J Neurosci 19:7670-7678.

Hunt SP, Pini A, Evan G (1987) Induction of c-fos-like protein in spinal cord neurons following sensory stimulation. Nature 328:632-634.

Hylden JL, Nahin RL, Traub RJ, Dubner R (1991) Effects of spinal kappa-opioid receptor agonists on the responsiveness of nociceptive superficial dorsal horn neurons. Pain 44:187-193.

Iadarola MJ, Brady LS, Draisci G, Dubner R (1988) Enhancement of dynorphin gene expression in spinal cord following experimental inflammation: stimulus specificity, behavioral parameters and opioid receptor binding. Pain 35:313-326.

Impey S, Obrietan K, Wong ST, Poser S, Yano S, Wayman G, Deloulme JC, Chan G, Storm DR (1998) Cross talk between Erk and PKA is required for $\mathrm{Ca}^{2+}$ stimulation of CREB-dependent transcription and Erk nuclear translocation. Neuron 21:869-883.

Impey S, Obrietan K, Storm DR (1999) Making new connections: role of ERK/MAP kinase signaling in neuronal plasticity. Neuron 23:11-14.

Ji RR, Rupp F (1997) Phosphorylation of transcription factor CREB in rat spinal cord after formalin-induced hyperalgesia: relationship to c-fos induction. J Neurosci 17:1776-1785. 
Ji RR, Woolf CJ (2001) Neruonal plasticity and signal transduction in nociceptive neurons: Implications for the initiation and maintenance of pathological pain. Neurobiol Dis 8:1-10.

Ji RR, Zhang X, Wiesenfeld-Hallin Z, Hokfelt T (1994) Expression of neuropeptide Y and neuropeptide Y (Y1) receptor mRNA in rat spinal cord and dorsal root ganglia following peripheral tissue inflammation. J Neurosci 14:6423-6434.

Ji RR, Zhang X, Nilsson S, Wiesenfeld-Hallin Z, Hokfelt T (1995) Central and peripheral response to galanin induced by inflammation. Neuroscience 68:563-576.

Ji RR, Schlaepfer TE, Aizenman CD, Qiu D, Hung JC, Rupp F (1998) Repetitive transcranial magnetic stimulation activates specific neural regions. Proc Natl Acad Sci USA 95:15635-15640.

Ji RR, Baba H, Brenner G, Woolf CJ (1999) Nociceptive-specific activation of ERK in spinal neurons contributes to pain hypersensitivity. Nat Neurosci 2:1114-1119.

Kuroki Y, Fukushima K, Kanda Y, Mizuno K, Watanabe Y (2001) Neuroprotection by estrogen via extracellular signal-regulated kinase against quinolinic acid-induced cell death in the rat hippocampus. Eur J Neurosci 13:472-476.

Laughlin TM, Vanderah TW, Lashbrook J, Nichols ML, Ossipov M, Porreca F, Wilcox GL (1997) Spinally administered dynorphin A produces long-lasting allodynia: involvement of NMDA but not opioid receptors. Pain 72:253-260.

Lewin MR, Walters ET (1999) Cyclie GMP pathway is critical for inducing long-term sensitization of nociceptive sensory neurons. Nat Neurosci 2:18-23.

Ma QP, Allochorne AJ, Woolf CJ (1998) Morphine, the NMDA receptor antagonist $\mathrm{MK} 801$ and tachykinin NK1 receptor antagonist RP67580 attenuate the development of inflammation-induced progressive tactile hypersensitivity. Pain 77:49-57.

Malan TP, Ossipov MH, Gardell LR, Ibrahim M, Bian D, Lai J, Porreca F (2000) Extraterritorial neuropathic pain correlates with multisegmental elevation of spinal dynorphin in nerve-injured rats. Pain 86:185-194.

Malmberg AB, Chen C, Susumu T, Basbaum AI (1997) Preserved acute pain and reduced neuropathic pain in mice lacking PKC gamma. Science 278:279-283.

Mannion RJ, Costigan M, Decosterd I, Amaya F, Ma QP, Holstege JC, Ji RR, Acheson A, Lindsay RM, Wilkinson GA, Woolf CJ (1999) Brainderived neurotrophic factor-a centrally acting modulator of tactile stimulus-induced inflammatory pain hypersensitivity. Proc Natl Acad Sci USA 96:9385-9390.

Marshall GE, Shehab SA, Spike RC, Todd AJ (1996) Neurokinin-1 receptors on lumbar spinothalamic neurons in the rat. Neuroscience 72:255-263.

McCarsson KE, Krause JE (1994) NK-1 and NK-3 type tachykinin receptor mRNA expression in the rat spinal cord dorsal horn is increased during adjuvant or formalin-induced nociception. J Neurosci 14:712-720.

Messersmith DJ, Kim DJ, Iadarola MJ (1998) Transcription factor regulation of prodynorphin gene expression following rat hindpaw inflammation. Mol Brain Res 53:260-269.

Molliver DC, Wright DE, Leitner ML, Parsadanian AS, Doster K, Wen D, Yan Q, Snider WD (1997) IB4-binding DRG neurons switch from NGF to GDNF dependence in early postnatal life. Neuron 19:849-861.

Nahin RL, Hylden JL, Iadarola MJ, Dubner R (1989) Peripheral inflammation is associated with increased dynorphin immunoreactivity in both projection and local circuit neurons in the superficial dorsal horn of the rat lumbar spinal cord. Neurosci Lett 96:247-252.

Neumann S, Doubell TP, Leslie T, Woolf CJ (1996) Inflammatory pain hypersensitivity mediated by phenotypic switch in myelinated primary sensory neurons. Nature 384:360-364.

Nichols ML, Lopez Y, Ossipov MH, Bian D, Porreca F (1997) Enhancement of the antiallodynic and antinociceptive efficacy of spinal morphine by antisera to dynorphin A (1-13) or MK-801 in a nerve-ligation model of peripheral neuropathy. Pain 69:317-322.

Nichols ML, Allen BJ, Rogers SD, Ghilardi JR, Honore P, Luger NM, Finke MP, Li J, Lappi DA, Simone DA, Mantyh PW (1999) Transmission of chronic nociception by spinal neurons expressing the substance P receptor. Science 286:1558-1561.

Noguchi K, Morita Y, Kiyama H, Ono K, Tohyama MA (1988) Noxious stimulus induces the preprotachykinin-A gene expression in the rat dorsal root ganglion: a quantitative study using in situ hybridization histochemistry. Brain Res 464:31-35.

Obrietan K, Impey S, Smith D, Athos J, Storm DR (1999) Circadian regulation of CAMP response element-mediated gene expression in the suprachiasmatic nuclei. J Biol Chem 274:17748-17756.

Ren K, Iadarola MJ, Dubner R (1996) An isobolographic analysis of the effect of $N$-methyl-D-aspartate and NK1 tachykinin receptor antagonists on inflammatory hyperalgesia in the rat. $\mathrm{Br} J$ Pharmacol 117:196-202.

Roberson ED, English JD, Adams JP, Selcher JC, Kondratick C, Sweat JD (1999) The mitogen-activated protein kinase cascade couples PKA and $\mathrm{PKC}$ to CAMP response element binding protein phosphorylation in area CA1 of hippocampus. J Neurosci 19:4337-4348.

Ruda MA, Iadarola MJ, Cohen LV, Young WS (1988) In situ hybridization histochemistry and immunohistochemistry reveal an increase in spinal dynorphin biosynthesis in rat model of peripheral inflammation and hyperalgesia. Proc Natl Acad Sci USA 85:622-626.

Samad A, Moore KA, Sapirstein A, Billet S, Allchorne A, Poole S, Bonventre JV, Woolf CJ (2001) An interleukin-1b-mediated induction of Cox-2 in the central nervous system contributes to inflammatory pain hypersensitivity. Nature 22:471-475.

Schafer MK, Nohr D, Krause JE, Weihe E (1993) Inflammationinduced upregulation of NK1 receptor mRNA in dorsal horn neurons. NeuroReport 4:1007-1010.

Sgambato V, Pages C, Rogard M, Besson MJ, Caboche J (1998) Extracellular signal-regulated kinase (ERK) controls immediate early gene induction on corticostrital stimulation. J Neurosci 18:8814-8825.

Stein C, Millan MJ, Herz A (1988) Unilateral inflammation of the hindpaw in rats as a model of prolonged noxious stimulation: alterations in behavior and nociceptive thresholds. Pharmacol Biochem Behav 31:445-451.

Trafton JA, Basbaum AI (2000) The contribution of spinal cord neurokinin-1 receptor signaling to pain. J Pain Suppl 1:57-65.

Traub RJ (1996) The spinal contribution of substance P to the generation and maintenance of inflammatory hyperalgesia in the rat. Pain 67:151-161.

Wang Z, Gardell LR, Ossipov MH, Vanderah TW, Brennan MB, Hochgeschwender U, Hruby VJ, Malan Jr TP, Lai J, Porreca F (2001) Pronociceptive actions of dynorphin maintain chronic neuropathic pain. J Neurosci 21:1779-1786.

Wegert S, Ossipov MH, Nichols ML, Bian D, Vanderah TW, Malan TP Jr, Porreca F (1997) Differential activities of intrathecal MK-801 or morphine to alter responses to thermal and mechanical stimuli in normal or nerve-injured rats. Pain 71:57-64.

Winder DG, Martin KC, Muzzio IA, Rohrer D, Chruscinski A, Kobilka B, Kandel ER (1999) ERK plays a regulatory role in induction of LTP by theta frequency stimulation and its modulation by b-adrenergic receptors. Neuron 24:715-726.

Wisden W, Errington ML, Williams S, Dunnett SB, Waters C, Hitchcock D, Evan G, Bliss TVP, Hunt SP (1990) Differential expression of immediate early genes in the hippocampus and spinal cord. Neuron 4:603-614.

Woolf CJ (1983) Evidence for a central component of post-injury pain hypersensitivity. Nature 306:686-688.

Woolf CJ, Costigan M (1999) Transcriptional and post-translational plasticity and the generation of inflammatory pain. Proc Natl Acad Sci USA 96:7723-7730.

Woolf CJ, Salter MW (2000) Neuronal plasticity: increasing the gain in pain. Science 288:1765-1769.

Woolf CJ, Wall PD (1986) Relative effectiveness of C primary afferent fibers of different origins in evoking a prolonged facilitation of the flexor reflex in the rat. J Neurosci 6:1433-1442.

Woolf CJ, Mannion RJ, Neumann S (1998) Null mutations lacking substance: elucidating pain mechanisms by genetic pharmacology. Neuron 20:1063-1066.

Xia Z, Dudek H, Miranti CK, Greenberg ME (1996) Calcium influx via the NMDA receptor induces immediate early gene transcription by a MAPK/ERK-dependent mechanism. J Neurosci 16:5425-5436.

Xing J, Ginty DD, Greenberg ME (1996) Coupling of the RAS-MAPK pathway to gene activation by RSK2, a growth factor-regulated CREB kinase. Science 273:959-963. 